\title{
The Effectiveness of Guided Discovery Based Learning Materials to Increase Students' Learning Outcomes
}

\author{
Devi Evylia Purmawanti \\ Science Education Program, Postgraduate School \\ Universitas Negeri Surabaya \\ Surabaya, Indonesia
}

\author{
Utiya Azizah \\ Chemistry Department \\ Universitas Negeri Surabaya \\ Surabaya, Indonesia \\ utiyaazizah@unesa.ac.id
}

\author{
Sari Edi Cahyaningrum \\ Chemistry Department \\ Universitas Negeri Surabaya \\ Surabaya, Indonesia
}

\begin{abstract}
This research aimed to know the effectiveness of learning materials based on guided discovery increasing students' learning outcomes. The research model used in this study was Research and Development (R\&D), but it is only limited to the development stage, namely by conducting a trial I. Trial I was conducted on 30 students of class XI Mia 1 of Senior High School Muhammadiyah 3 Surabaya. The research design used was one group pretest posttest design. The results showed that the effectiveness of the learning device was obtained from the results of learning and student responses. Learning outcomes are obtained through student learning outcomes assessment sheets on thermochemical material, while the response results are obtained from the questionnaire response sheet. The results obtained were analyzed by quantitative descriptive way. The results showed that the guided discovery learning device succeeded in increasing the number of learning outcomes by as much as $20 \%$ in the medium category and $80 \%$ in the high category, besides that most students gave positive responses to the learning materials developed.
\end{abstract}

\section{Keywords—guided discovery, learning outcomes}

\section{INTRODUCTION}

Life in the global era demands a variety of educational changes caused by the development of Science and Technology which is increasingly growing rapidly, so that it can help increase the potential of students in building the nation in the life of the future. The education process serves as a tool to achieve educational goals namely the competencies that must be achieved. In line with that [1] explained that each education unit conducts learning planning, implements the learning process, and evaluates the learning process to improve the efficiency and effectiveness of graduate competencies.

One of the efforts to reform the National Education System is to renew the education curriculum in Indonesia. The curriculum currently being implemented is the 2013 curriculum. According to [2] stated that the 2013 curriculum emphasizes character education, especially at the basic level which aims to improve the quality of the educational process and outcomes, which lead to the formation of character and noble character of students in full, integrated and balanced in accordance with the competency standards of graduates in each educational unit. On the other hand, [3] states that the 2013 Curriculum development policy is themed; produce productive, creative, innovative, and affective Indonesian people through strengthening integrated attitude (knowing why), skill (knowing how), and knowledge (knowing what).

Permendikbud (2016) the Number.22, mention the learning principles used in the 2013 Curriculum, some of which: (i) students are told to learn about them; (ii) from the teacher as the only source of learning to be learning based on various learning resources; (iii) from a textual approach to a process to strengthen the use of scientific approaches; and (iv) improvement and balance between hard skills and soft skills. Achieving the objectives of the 2013 curriculum is one of the most important roles of a teacher. [4] that teachers are expected to be creative and innovative in developing learning strategies to realize a more meaningful teaching and learning process with high student achievement. Then learning is needed with a scientific approach. For the sake of the realization of learning with a scientific approach, one way that can be done is by guided discovery oriented learning.

Guided discovery learning is a learning model that trains and guides students to learn, gain knowledge, and build concepts they find for themselves [5]. In accordance with the demands of Curriculum 13, where students are expected to be more actively involved and not only depend on the explanation from the teacher. Wilcox in [6] states that guided discovery motivates students to learn through their own involvement with concepts and principles. The process of concept discovery is done by way of students observing, classifying, hypothesizing, explaining, formulating conclusions and so on to find some concepts or principles. Pe guided discovery learning can be applied one of them to the subject of chemistry about thermochemistry.

Thermochemistry is the study of heat changes that accompany chemical reactions and phase changes [7]. This material is abstract because students apply reaction equations and thermochemical formulas into count problems. This statement is supported by research results [8] states that thermochemical material is still considered difficult and unattractive because in this material students still find it difficult to apply thermochemical formulas and reactions into 
count problems and are shown from the daily repetition of thermochemical material as much as $40 \%$ of students are still below the completeness criteria value The minimum chemistry lesson is 2.67 .

The results of the field study showed that $54.55 \%$ did not understand the chemistry delivered by the teacher and $63 \%$ of the students received daily tests below the minimum completion criteria. Contrary to students' understanding, $84.85 \%$ of students liked the thermochemical material, one of the reasons was $78.79 \%$ of the students liked to do practicum in thermochemical material and $93.94 \%$ stated that thermochemical material needed to be taught through practicum.

Based on the description of the problems above, it is necessary to conduct a research entitled "The Effectiveness of Guided Discovery Based Learning Materials to Increase Students' Learning Outcomes".

\section{METHODS}

This study measured the effectiveness of guided discovery oriented learning materials to increase students' learning outcomes. The research design used in this study is the Research and Development (R\&D) design of [9]. The R\&D design has three steps as follows: preliminary study, development and testing. In this research is limited to the study of the development phase of the first trial (small-scale trials). In limited trials using the type of one group pretest posttest research, that is, without a comparison group. The research subjects used in this study were 30 students of class XI Mia 1 of Senior High School Muhammadiyah 3 Surabaya in the academic year 2018/2019.

The research method used to determine the effectiveness of the feasibility of the device is a test technique to determine the learning outcomes of aspects of knowledge and questionnaire techniques to determine student responses. The instrument used to determine the increasing of learning outcomes aspects of knowledge is a test result sheet in the form of pretest and posttest essay questions. Learning outcomes data were used to determine students' learning completeness in cognitive aspects of thermochemical material. Students' learning outcomes are calculated using the following formulas:

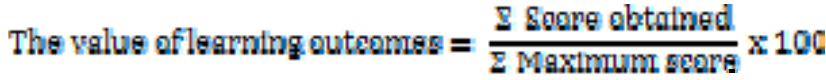

Achievement of knowledge competence is converted into the predicate of A to D in accordance with [10] contained in Table 1.

\section{TABLE I. CONVERTING INDIVIDUAL COMPLETENESS VALUES} INTO PREDICATES

\begin{tabular}{|c|c|}
\hline $\begin{array}{c}\text { Value of Knowledge } \\
\text { Competence }\end{array}$ & Predicate \\
\hline$<80$ & D (Less) \\
\hline $80-85$ & C (Enough) \\
\hline $86-90$ & B (Good) \\
\hline $91-100$ & A (Excellent) \\
\hline
\end{tabular}

Based on Table I above it can be seen that student learning outcomes are said to be complete if they got a value of $\geq 80$ with the $\mathrm{C}$ predicate. Increasing student learning outcomes pretest and posttest were analyzed using the n-gain score, according to the formula by [11] follows:

$$
n-g \text { ath }=\frac{\text { Valus partest }- \text { Valus pretest }}{\text { Valus }}
$$

Furthermore, the criteria for increasing learning outcomes are determined, if $\mathrm{g}<0.3$ includes the low criteria, $0.3 \leq \mathrm{g}<0.7$ includes the medium criteria, and $\mathrm{g} \geq 0.7$ includes the high criteria. The questionnaire response instrument was used to determine the response to the learning materials that was developed as well as responses to guided discovery-oriented learning provided by the researcher. Questionnaire responses of students contain filling instructions, statements and yes-no columns. Respect data were analyzed using the following formula:

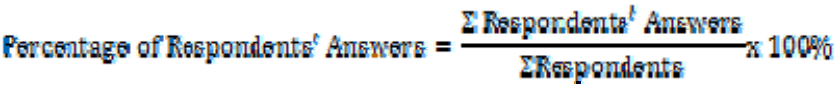

The percentage obtained is then interpreted into criteria according to [12] which are listed in Table II.

TABLE II. INTERPRETATION OF STUDENT RESPONSE SCORES

\begin{tabular}{|c|c|}
\hline Persentase (\%) & Kriteria \\
\hline $0-20$ & Very less \\
\hline $21-40$ & Less \\
\hline $41-60$ & Enough \\
\hline $61-80$ & Good \\
\hline $81-100$ & Excellent \\
\hline
\end{tabular}

Based on Table II above the guided discovery oriented learning materials on the thermochemical material developed received a positive response from students if the percentage of students who answered "Yes" $\geq 61 \%$.

\section{RESULTS AND DISCUSSION}

\section{A. Results}

The effectiveness of the developed learning materials can be measured from the results of knowledge tests on thermochemical material and questionnaire responses after using the learning materials. Students are said to be complete if they got a value of $\geq 80$ with predicate $C$, while the results of students' responses are said to be positive if they answer "Yes" $\geq 61 \%$.

1) Analysis of students' learning outcomes results: The results of learning outcomes tests had been obtained and the average value obtained at pretest is 20.1 and posttest is 84.2. These results indicate that most students increase learning outcomes.

The N-gain score obtained by $20 \%$ is included in the medium criteria and $80 \%$ in the high criteria. The recapitulation of learning outcomes tests is presented in table III below.

TABLE III. RESULT OF LEARNING OUTCOMES

\begin{tabular}{|c|c|c|c|c|}
\hline No. & $\begin{array}{c}\text { Value of } \\
\text { Pretest }\end{array}$ & $\begin{array}{c}\text { Value of } \\
\text { Posttest }\end{array}$ & n-gain & Criteria \\
\hline 1 & 20 & 75 & 0.69 & Medium \\
\hline 2 & 16 & 87 & 0.85 & High \\
\hline 3 & 14 & 78 & 0.74 & High \\
\hline 4 & 22 & 86 & 0.82 & High \\
\hline 5 & 24 & 80 & 0.74 & High \\
\hline
\end{tabular}




\begin{tabular}{|c|c|c|c|c|}
\hline No. & $\begin{array}{c}\text { Value of } \\
\text { Pretest }\end{array}$ & $\begin{array}{c}\text { Value of } \\
\text { Posttest }\end{array}$ & n-gain & Criteria \\
\hline 6 & 12 & 86 & 0.84 & High \\
\hline 7 & 20 & 79 & 0.74 & High \\
\hline 8 & 21 & 89 & 0.87 & High \\
\hline 9 & 26 & 91 & 0.87 & High \\
\hline 10 & 16 & 74 & 0.69 & Medium \\
\hline 11 & 25 & 93 & 0.91 & High \\
\hline 12 & 20 & 72 & 0.65 & Medium \\
\hline 13 & 21 & 91 & 0.88 & High \\
\hline 14 & 14 & 88 & 0.86 & High \\
\hline 15 & 20 & 74 & 0.68 & Medium \\
\hline 16 & 27 & 93 & 0.90 & High \\
\hline 17 & 24 & 89 & 0.86 & High \\
\hline 18 & 20 & 91 & 0.88 & High \\
\hline 19 & 13 & 87 & 0.85 & High \\
\hline 20 & 16 & 73 & 0.68 & Medium \\
\hline 21 & 28 & 91 & 0.87 & High \\
\hline 22 & 25 & 89 & 0.86 & High \\
\hline 23 & 20 & 92 & 0.90 & High \\
\hline 24 & 22 & 80 & 0.74 & High \\
\hline 25 & 24 & 89 & 0.86 & High \\
\hline 26 & 15 & 72 & 0.67 & Medium \\
\hline 27 & 14 & 81 & 0.78 & High \\
\hline 28 & 20 & 84 & 0.79 & High \\
\hline 29 & 22 & 93 & 0.91 & High \\
\hline 30 & 22 & 80 & 0.74 & High \\
\hline & & & & \\
\hline
\end{tabular}

2) Analysis of student responses results: The response questionnaire included an assessment of the learning process and also the materials used. The results of student responses are presented in table IV below.

TABLE IV. RESULT OF STUDENT RESPONSES

\begin{tabular}{|c|c|c|c|}
\hline No. & Aspect & $\begin{array}{l}\text { Response } \\
\text { Persentage } \\
(\%)\end{array}$ & Criteria \\
\hline \multirow[t]{2}{*}{ I. } & $\begin{array}{l}\text { Based on the learning you have } \\
\text { done, are you interested in the } \\
\text { following components? }\end{array}$ & Interested & \\
\hline & $\begin{array}{l}\text { Materials, Worksheets, Learning } \\
\text { atmosphere, The way the teacher } \\
\text { teaches }\end{array}$ & $83,3-96,7$ & $\mathrm{E}$ \\
\hline \multirow[t]{2}{*}{ II. } & $\begin{array}{l}\text { Do you find it easy to understand } \\
\text { the components in the following } \\
\text { worksheet? }\end{array}$ & Easy & \\
\hline & $\begin{array}{l}\text { Material, Phenomena, } \\
\text { Descriptions, or Explanations, } \\
\text { Questions, Information, and } \\
\text { Terms }\end{array}$ & $80-90$ & $\mathrm{G}-\mathrm{E}$ \\
\hline \multirow[t]{2}{*}{ III. } & $\begin{array}{l}\text { Do you agree with the following } \\
\text { components: }\end{array}$ & Agree & \\
\hline & $\begin{array}{l}\text { Presentation of worksheets can } \\
\text { motivate to learn, encourage to be } \\
\text { active, arouse curiosity, } \\
\text { presentation of images helps } \\
\text { understand material, formulas and } \\
\text { symbols clearly stated. }\end{array}$ & $83,3-90$ & $\mathrm{E}$ \\
\hline \multirow[t]{2}{*}{ IV. } & $\begin{array}{l}\text { Are you able to follow the } \\
\text { following components? }\end{array}$ & Yes & \\
\hline & $\begin{array}{l}\text { Make questions \& hypotheses, } \\
\text { experiment, make conclusions, } \\
\text { reflect }\end{array}$ & $86,7-96,7$ & $\mathrm{E}$ \\
\hline \multirow[t]{2}{*}{ V. } & $\begin{array}{l}\text { What do you think about the way } \\
\text { the teacher provides learning with } \\
\text { guided discovery models? }\end{array}$ & Good & \\
\hline & First to sixth guided discovery & $83,3-96,7$ & $\mathrm{E}$ \\
\hline
\end{tabular}

\begin{tabular}{|c|l|c|c|}
\hline \multirow{2}{*}{ No. } & \multicolumn{1}{|c|}{ Aspect } & $\begin{array}{c}\text { Response } \\
\text { Persentage } \\
(\%)\end{array}$ & Criteria \\
\hline & stages & & \\
\hline VI. & $\begin{array}{l}\text { Do you find it easy to answer the } \\
\text { test results of learning outcomes? }\end{array}$ & Easy & \\
\cline { 3 - 4 } VII. & $\begin{array}{l}\text { Are you interested in } \\
\text { participating in the learning as } \\
\text { you have done now to be applied } \\
\text { to the next learning activities? }\end{array}$ & Interested & $\mathrm{G}$ \\
\hline
\end{tabular}

Note: $\mathrm{G}=$ Good

$\mathrm{E}=$ Excellent

\section{B. Discussion}

Learning outcomes test is given at the beginning of learning with the aim of knowing students' knowledge on thermochemical material before the trial and after the learning process students are given a posttest to find out the learning outcomes of students after participating in guided discovery oriented learning. This test is used to measure the level of understanding of students in the realm of knowledge related to Basic Competence 3.4, which is understanding the concept of $\Delta \mathrm{H}$ as a heat reaction at constant pressure and its use in thermochemical equations. Basic Competence 3.5, which is understanding various types of reaction enthalpies (enthalpy of formation, enthalpy of combustion, etc.), Hess's law and the concept of bond energy. The test sheet contains 10 essay questions that refer to the cognitive domain of C3 C6 and represent indicators on thermochemical material.

Learning outcomes test consists of 10 breakdown questions. Questions number 1, 2, 3, 4, and 5 regarding exothermic and endothermic reactions related to Basic Competence 3.4. This concept has been learned by students at meeting 1 . The results of the pretest in problem number 1 shows that the scores obtained ranged from 0 to 3 of the maximum score obtained by 10 . At the time of the posttest students were able to correctly answer question number 1 with the score obtained between $4-10$, but overall students are able to answer correctly with a score of 10 . These results indicate that learning at the first meeting is effective in improving learning outcomes regarding exothermic and endothermic reactions.

The concepts learned at the second meeting consisted of Hess's Law, Enthalpy of Establishment of Standards, Bonding Energy related to Basic Competence 3.5. Students' mastery of these concepts is tested through questions number $6,7,8,9$, and 10 . The lowest overall posttest is found in questions numbers 6,8 , and 10 relating to calculating $\Delta \mathrm{H}$ reactions based on Hess's law, data on enthalpy changes in standard formation, and bond energy data. Overall students still find it difficult to solve problems that are counted, because of the many calculation formulas used in thermochemical material so they are confused about applying the formula in solving problems.

At the time of the pretest all students get a grade with the predicate $\mathrm{D}$ which indicates that there are no students who have completed the thermochemical material. This is because students have not received the material so students do not understand the concepts in thermochemical material. Guided discovery learning also provides students the opportunity to learn in groups, because group learning can develop cognitive and social interactions. Based on Vygotsky's 
constructivist theory shows that social interactions with other friends spur the formation of new ideas and enrich the intellectual development of students [13].

Piaget's theory states that learning is related to the formation and development of schemes [13]. This scheme is a cognitive structure that can make someone adapt and coordinate the surrounding environment by using intellectuals that involve the process of assimilation and accommodation. After students take part in learning by using guided discovery oriented learning materials, it can be seen that almost all students are declared complete, that is, those who get predicate $\mathrm{A}, \mathrm{B}$, and $\mathrm{C}$.

Based on Table III shows that the results of the pretest as much as $100 \%$ are incomplete and have decreased to $27 \%$ incomplete originating from 8 students who scored with the predicate $\mathrm{D}$. The eight students get the $\mathrm{D}$ predicate because they unable to answer the questions in the test well at numbers 6,8 and 10 , while $73 \%$ of students complete at the time of the posttest.

Based on the comparison of the values obtained from the pretest and posttest shows that guided discovery oriented learning can improve student learning outcomes as indicated by the posttest scores obtained. This is supported by research results [14] that students who were taught chemistry with Guided Discovery Instruction Strategies obtained an average score of 15.1 higher than students who were taught chemistry using conventional methods which scored 12.4. According to [15] which states that the guided discovery oriented learning device developed can improve the completeness of student learning outcomes seen based on the pretest value where all students are incomplete.

Improvement of student learning outcomes on thermochemical material can be seen from the n-gain score. The n-gain score shows the difference in values obtained by students during the pretest and posttest. This can be seen from the n-gain score above 0.7 , while the rest experienced an increase in the moderate category of n-gain scores from 0.65 to 0.69 . Overall, it can be said that the learning outcomes of all students have increased. This increase means that the learning outcomes of students who were initially still low after learning have increased to high. The percentage increase in student learning outcomes obtained by $20 \%$ belongs to the medium category while $80 \%$ is included in the high category. Based on these results, it can be said that learning using guided discovery oriented learning materials that have been carried out effectively in increased student learning outcomes towards thermochemical material.

Student responses to learning are assessed based on: (1) interest in the learning process and learning materials; (2) ease of understanding the components of the worksheet; (3) approval of the presentation in the worksheet by learning; (4) participation in guided discovery oriented learning; (5) the way the teacher provides learning with the guided discovery model; (6) ease of answering test questions; and (7) the desire to implement similar learning in other material. Student responses are responses to the guided discovery oriented learning materials that has been implemented. Student response data obtained from the results of a questionnaire given to students at the end of learning the third meeting.
Based on Table IV it can be seen that in terms of students' interest in the subject matter / content, learning atmosphere, the way the teacher teaches and the stages of learning directed by the teacher get a very good response with the percentage of responses ranging from $83.3 \%-100 \%$ which states that students are very interested. The response of students' interest towards the atmosphere of learning is still classified in the very good category, indicating that students feel comfortable with the atmosphere of learning in groups, discussing, and experimenting. Students are in groups so they can discuss if they have difficulty in conducting experiments / experiments to solve the problems presented.

Interest in worksheet was expressed by $93.3 \%$ of students. The stages of learning were also responded to very well by students which amounted to $96.7 \%$. Worksheet developed there is a phenomenon in the form of narration and is equipped with images. The chosen phenomenon is an event / fact related to daily life so that it is familiar to students. In line with this [16] explain that students more easily understand a particular concept if the explanation starts from the easy or something that is concrete, something real is in their environment.

In terms of student worksheet, information and terms are easily understood to get a percentage of $80 \%-90 \%$. That is because the terms written in worksheet are adjusted to the literature and textbooks at the Senior High School level in general. Additional information included is information relating to the daily lives of students, which are already known to students but not too profound so that through this information the students will know more deeply. Similarly, the material that gets a percentage of $80 \%$. Furthermore, the results of the response in terms of questions and phenomena, descriptions or explanations that obtain a percentage with a range of values of $80 \%-93.3 \%$ with a good category.

The results of the response in terms of approval of the presentation contained in the worksheet by learning obtained a percentage range of $83.3 \%$ - 90\%. As many as $90 \%$ $93.3 \%$ of worksheet presentation can motivate students to learn. This is because students assume that the worksheet used is more attractive both in terms of content, presentation and stages that have never been done before. In addition, at the time of learning at the first and second meetings many of the students asked questions and the teacher had to lead from one stage to the next.

In terms of participation in guided discovery oriented learning, students can follow the stages of learning with a range of $86.7 \%$ - $96.7 \%$. Overall the stages of making conclusions obtained the lowest percentage compared to the other stages. This is because students are accustomed to depend on the teacher's explanation and are not trained to analyze the problems presented.

The way teachers teach oriented discovery at each stage of learning also gets excellent responses from students with a range of $83.3 \%-96.7 \%$. The percentage on the teacher aspect can motivate students to learn is obtained by $90 \%$. Motivation is given by displaying images related to the material to be studied. After that, students are given an investigation problem in the form of phenomena and guided to focus on the problem in order to make questions. 
In terms of students' interest in the guided discovery learning model, $86.7 \%$ stated that they were interested in participating and agreed if the learning was applied at the next meeting. This proves that students are happy with learning that encourages them to be active both in discussions and in the process of discovery.

Overall, all aspects of guided discovery-oriented learning materials get responses in both good and excellent categories so that it can be said that the learning materials developed are practical for use in the learning process.

\section{CONCLUSIONS}

Based on the results and discussion of research, it can be concluded that the effectiveness of guided discovery oriented learning tool materials to increase learning outcomes on thermochemical topics. The instrument used in the form of a test result sheet to measure aspects of student knowledge and the results obtained that student learning outcomes increased at the time of the posttest with an n-gain score of $20 \%$ included in the medium criteria and $80 \%$ included in the high criteria. Other instruments, namely the questionnaire response sheet to measure student responses after the use of learning materials and the results obtained that students gave a positive response to the devices.

\section{ACKNOWLEDGMENT}

Researchers thanks to Mrs. Hariyatini as a chemistry teacher and 30 students from grade XI Mia 1 of Senior High School Muhammadiyah 3 Surabaya for research assistance to obtain effectiveness data from the learning materials that had been developed.

\section{REFERENCES}

[1] Permendikbud. (2016). Peraturan Menteri Pendidikan dan Kebudayaan Republik Indonesia Nomor 22 Tahun 2016 Tentang Standar Proses Pendidikan Dasar dan Menengah. Jakarta: Menteri Pendidikan dan Kebudayaan RI

[2] Mulyasa, E. (2015). Pengembangan dan Implementasi Kurikulum 2013. Bandung: PT Remaja Rosdakarya
[3] Hosnan, M. (2014). Pendekatan Saintifik dan Kontekstual dalam Pembelajaran Abad 21. Cetakan Pertama. Bogor: Penerbit Ghalia Indonesia

[4] Luthfi, A.I., Danial M., \& Wijaya M. (2016). Perbandingan Metode Pemberian Tugas Kerja Kelompok dengan Kerja Indvidu pada Model Pembelajaran Discovery Learning Terhadap Hasil Belajar Peserta Didik Kelas XI MIA SMAN 1 Tondong Tallasa Kab. Pangkep (Studi pada Materi Pokok Termokimia). Jurnal Chemica, 58 - 66

[5] Carin, A.A. (1993). Teaching Science through Discovery. $7^{\text {th }}$ Edition. New York: Macmillan Publishing Company

[6] Nur, M. (2008). Pengajaran Berpusat pada Siswa dan Pendekatan Konstruktivis dalam Pengajaran. Edisi Kelima. Surabaya: Universitas Negeri Surabaya (PSMS)

[7] Buthelezi, T., Dingrando, L., Hainen, N., Wistrom, C., Zike, D. (2008). Glencoe Science Chemistry: Matter and Change. New York: McGraw Hill

[8] Sugita, N. T. H., Ashadi \& Masykuri M. (2016). Pengaruh Model Pembelajaran Problem Solving dan Problem Posing Terhadap Hasil Belajar Ditinjau dari Kreativitas Siswa pada Materi Termokimia Kelas XI SMA Negeri 1 Karanganyar Tahun Pelajaran 2015/2016. Jurnal Pendidikan Kimia, 59 - 67

[9] Sukmadinata, N.S. (2015). Metode Penelitian Pendidikan. Bandung: PT Remaja Rosdakarya

[10] Kemendikbud. (2016). Panduan Penilaian oleh Pendidikdan Satuan Pendidikan untuk Sekolah Menengah Atas. Diperoleh pada tanggal 1 Januari 2018 dari https://www.bsnp-indonesia.org.

[11] Hake, R.R. (1998). Interactive Engagement Versus Traditional Methods: A Six Thousand Student Survey of Mechanics Test Data for Introductory Physics Courses. American Journal Physics, 64 - 74

[12] Riduwan. (2015). Dasar- Dasar Statistika. Bandung: Alfabeta

[13] Slavin, R.E. (2011). Psikologi Pendidikan: Teori dan Praktik. Edisi Kedelapan. Terjemahan Marianto Samosir. Jakarta: PT Indeks.

[14] Akani, O. (2017). Effect of Guided Discovery Method of Instruction and Students' Achievement in Chemistry at the Secondary School Level in Nigeria. International Journal of Scientific Research And Education, Volume 5|| Issue 02 || February-2017 || Pages-6226-6234 || ISSN(e):2321-7545

[15] Roosyanti, A. (2017). Pengembangan Perangkat Pembelajaran Berorientasi Pendekatan Guided Discovery untuk Melatihkan Keterampilan Berpikir Kritis dan Kreatif. Jurnal Pena Sains, 60 - 73

[16] Departemen Pendidikan Nasional. (2008). Panduan Pengembangan Bahan Ajar. Jakarta: Departemen Pendidikan Nasional Direktorat Jenderal Manajemen Pendidikan Dasar dan Menengah Direktorat Pembinaan Sekolah Menengah Atas 